Religious Studies (2021) 57, 717-731 (c) The Author(s), 2020. Published by Cambridge University Press. This is an Open Access article, distributed under the terms of the Creative Commons Attribution licence (http://creativecommons.org/licenses/by/4.0/), which permits unrestricted re-use, distribution, and reproduction in any medium, provided the original work is properly cited. doi:10.1017/S0034412520000050

\title{
On where God isn't: excrement and the philosophy of religion; two Jewish perspectives
}

\author{
SAMUEL LEBENS \\ Department of Philosophy, University of Haifa, 199 Abba Khoushy Avenue, Haifa, \\ 3498838, Israel \\ e-mail: slebens@univ.haifa.ac.il
}

\begin{abstract}
Milan Kundera suggests that human excrement poses a special problem for classical theism. Is there really a problem here, and if there is, how might the theist respond? This article explores Jewish sources in order to construct a real philosophical problem from Kundera's concern, and suggests two responses to that problem, both, once again, drawn from the Jewish tradition.
\end{abstract}

\section{Introduction: the problem with poo}

Few people have given voice to the profound religious and existential questions that arise from human excrement as well as Milan Kundera in The Unbearable Lightness of Being. He tells a story - partly based on fact - about the death of Stalin's son, Yakov. I quote:

Captured by the Germans during the Second World War, he was placed in a camp together with a group of British officers. They shared a latrine. Stalin's son habitually left a foul mess. The British officers resented having their latrine smeared with shit, even if it was the shit of the son of the most powerful man in the world. They brought the matter to his attention. He took offense. They brought it to his attention again and again, and tried to make him clean the latrine. He raged, argued, and fought. Finally, he demanded a hearing with the camp commander. He wanted the commander to act as arbiter. But the arrogant German refused to talk about shit. Stalin's son could not stand the humiliation. Crying out to heaven in the most terrifying of Russian curses, he took a running jump into the electrified barbed-wire fence that surrounded the camp. He hit the target. His body, which would never again make a mess of the Britishers' latrine, was pinned to the wire.

(Kundera (1995), 237) 
As Kundera imagines it, Stalin's son was used to carrying a heavy existential burden upon his shoulders. According to Kundera, his father, one of the most powerful men on earth, had most probably had his mother killed (this isn't true, but it certainly is true that Stalin and his son had a difficult relationship; and Stalin killed people close to his son). In Kundera's words, 'Young Stalin was therefore both the Son of God (because his father was revered like God) and His cast-off' (ibid.).

It is in the context of this sublime and existential drama that Stalin's son, as Kundera imagines it, was pulled down into a debate about excrement.

Was he, who bore on his shoulders a drama of the highest order (as fallen angel and Son of God), to undergo judgment not for something sublime (in the realm of God and the angels) but for shit? Were the very highest of drama and the very lowest so vertiginously close? . . If rejection and privilege are one and the same, if there is no difference between the sublime and the paltry, if the Son of God can undergo judgment for shit, then human existence loses its dimensions and becomes unbearably light.

(ibid.)

As the body of Stalin's son was stuck to that fence, in defiance of gravity, it was 'lifted by the infinite lightness of a world that [had] lost its dimensions' (ibid.). The story of the young Stalin, in Kundera's novel, vividly dramatizes something at the heart of human experience.

On the one hand, we like to imagine that we are each the protagonist in a meaningful story. In terms drawn from the Jewish tradition, we like to imagine that we are created in the image of God (Genesis 1:26-28), and that we are only a little lower than the angels (Psalm 8), and that we - personally - have been crowned with God's own glory and honour (ibid.). And yet, on the other hand, we cannot ignore the fact that we are animals. No wonder that we are so disgusted by our own faeces. It reminds us of our lowliness. Admittedly, there must be other factors in play. But, it has been noted that elicitors of disgust tend, also, to be reminders of death or of our animal nature (Rozin et al., 2008).

In a similar vein, the Talmud (tractate Sanhedrin 39a) describes why Adam had to be put to sleep before God would take his rib and fashion him a wife. It's not because God hadn't invented local anaesthetic. It's that God didn't want Adam to be conscious. He didn't want Adam to see the process of Eve's formation. Had Adam seen all of the gore, and the guts, and the blood, and the bile, as God fashioned her from Adam's rib, he would never have been able to find Eve attractive.

We hate to be reminded of our own humanity. It robs us of an important illusion. Perhaps part of the reason that so many of us find the thought of our parents making love a disturbing image is that, in actual fact, we owe our earthly existence to their copulation. We don't like to be reminded of the fact that we are animals. We don't wish to owe our existence to our father's ejaculation, and to our mother's ovulation.

On the surface of things, Jewish thought and practice could be thought to endorse this disgust; a disgust that's manifest particularly strongly regarding human faeces. In fact, Judaism might be thought to ritualize this disgust. 
The Talmud (tractate Berachot 25b) teaches us that we cannot pray opposite faeces unless it has been placed in a container. It's hard to concentrate on the sublime when you're smelling the foul stench of animal waste. Indeed, the Talmud (tractate Shabbat $40 \mathrm{ob}$ ) teaches us that we're not even allowed to think words of Torah - let alone speak them - whilst we're on the toilet. The Talmud also forbids prayer when a person needs to use the toilet (Tractate Brachot 15a and 23a). Whilst Maimonides explains this in terms of avoiding distraction during prayer (Mishne Torah, Prayer and Priestly Blessing, 4:10), a number of commentators argue that it isn't fitting for us to stand before the King of Kings whilst our insides are full of excrement ${ }^{1}$ - and indeed, this would make sense of the Talmud calling such prayer an abomination (Brachot 23a).

The Bible itself commands Jewish soldiers not to defecate in the camp, but rather to dig a hole outside the camp, in order to defecate, and then they must bury their droppings. Of course, this is good hygiene. It's also good for the soil. No doubt, human beings evolved a certain disgust for faeces because of the associated health risks. ${ }^{2}$ But the verses of the Torah provide an additional justification for these practices (Deuteronomy 23:15): 'Since the LORD your God moves about in your camp to protect you and to deliver your enemies to you, let your camp be holy; let Him not find anything unseemly among you and turn away from you.'3

From the verse, at least on an initial reading, it seems as if there really is something objectively filthy about faeces. It's not merely that it's unhealthy. It's not merely that the stench can make it hard for human beings to concentrate on sublime matters; though all of this is true. It's as if God Himself doesn't want to look at this stuff. Of course, this is highly anthropomorphic, but this anthropomorphism is there in the plain meaning of the text. Eventually, we'll want to interpret such theological vulgarities away, but, before doing so, it's still worth noticing the plain meaning of the biblical text. God, apparently, doesn't want to see our faeces. No wonder we shouldn't think thoughts of Torah in such a place. Indeed, Jewish law prohibits us from bringing books of Torah into that space, unless they're covered up (Shulchan Aruch, Y.D. 282:6).

But now a new dimension of the problem emerges: if God created it, and if it's not something that human beings choose to do (or can refrain from doing) of their own free will, then can it really be disgusting? Can the natural world of God's creation really contain filth? This theological problem is also developed by Kundera, in his novel. He writes:

\footnotetext{
When I was small and would leaf through the Old Testament retold for children and illustrated in engravings by Gustave Dore, I saw the Lord God standing on a cloud. He was an old man with eyes, nose, and a long beard, and I would say to myself that if He had a mouth, He had to eat. And if $\mathrm{He}$ ate, He had intestines. But that thought always gave me a fright, because even though I come from a family that was not particularly religious, I felt the idea of a divine intestine to be sacrilegious.

Spontaneously, without any theological training, I, a child, grasped the incompatibility of God and shit and thus came to question the basic thesis of Christian [and Jewish]
} 
anthropology, namely, that man was created in God's image. Either/or: either man was created in God's image - and God has intestines! - or God lacks intestines and man is not like Him.

(Kundera (1995), 239)

Now of course, this might be collapsed into the problem of evil. Why does God's creation contain bad things? But Kundera is careful to defuse that confusion. There's no indication that faeces is a moral evil; that you've done something wrong when you've gone to the toilet. Nor is it even a natural evil, unlike the diseases it can spread in its wake. It's more like an aesthetic defect. Is God's creation aesthetically perfect, or is it not? If we assume that disgust is an appropriate emotional response to faeces, then it seems that some portion of God's own creation is worthy of disgust. Relatedly, are we created in the image of God, or are we not? If we are, then why - as part of our very design in the image of God - do we defecate, given that defecation is worthy of disgust? And, if we're not created in the image of God, then isn't our religion founded upon a lie? As Kundera puts it: 'Shit is a more onerous theological problem than is [man-made/moral] evil. Since God gave man freedom, we can, if need be, accept the idea that He is not responsible for man's crimes. The responsibility for shit, however, rests entirely with Him, the Creator of man' (ibid.). The question most fundamentally at stake is this: is God's creation good? And here, we're not talking about moral goodness (though that's also an important question). Kundera continues:

Behind all the European faiths, religious and political, we find the first chapter of Genesis, which tells us that the world was created properly, that human existence is good, and that we are therefore entitled to multiply. Let us call this basic faith a categorical agreement with being.

The fact that until recently the word 'shit' appeared in print as s- has nothing to do with moral considerations. You can't claim that shit is immoral, after all! The objection to shit is a metaphysical one. The daily defecation session is daily proof of the unacceptability of Creation. Either/or: either shit is acceptable (in which case don't lock yourself in the bathroom!) or we are created in an unacceptable manner.

(ibid., 241)

Judaism is faced with a dilemma: do we embrace the categorical agreement with being, or don't' we? If we do, then why do we seem to have a poo-taboo enshrined in our ritual? If we don't, then how can we continue to believe that God's creation is good?

Before human free-choice has ruined the party, can God's creation contain material that's disgusting? Surely it could contain things that we would be wise to stay away from for reasons of hygiene, but can it contain things which are objectively worthy of disgust, such that Torah and Godliness cannot be in their proximity? I shall call objects that are objectively worthy of disgust, filthy. Can god's creation, before it has been sullied by the free choices of free actions, contain filth?

The problem can be formalized as follows:

1. Disgust is an appropriate emotional response to certain objects. 
2. Disgust can only be an appropriate emotional response to an object if that object is filthy (in my sense of the word).

3. Therefore, there are filthy objects. (from 1 and 2)

Line 3 is incompatible with the categorical agreement with being. Categorical agreement with being is a consequence of theism. Consequently, line 3 is incompatible with theism. The existence of poo, and any other filthy material - urine, for example, and other excreta - gives rise to an argument for atheism. The Jewish sources give rise to two very different responses. The first response seeks to place a wedge between theism and the categorical agreement with being; this would render line 3 compatible with theism. The second response seeks to deny premise 2, and thereby undermine line 3. Disgust might be, in some sense, appropriate, but it shouldn't be taken to entail that the objects of our disgust are, in any deep or objective sense, filthy or disgusting.

\section{Response 1: God's creation can contain filth}

We have to remember that the very act of creation was a decision, on God's part, to allow for the existence of the ungodly. As is understood by the Lurianic Kabala, God's act of creation required a prior act, on God's part, of withdrawal or concealment. If God was to allow room for the being of other things - i.e. His creations - then he would have to rein Himself in. He would have to create room for things other than Himself. ${ }^{4}$ Some Kabbalists took this metaphor quite literally. They thought of the world as existing within a godless space that God had made room for (or almost godless - they do still speak of a residue of Divinity left in the void).

Rabbi Immanuel Chai Ricchi (1688-1743) thought that taking God's contraction literally helped to escape the poo problem. If you don't take this doctrine literally, he says, then you insult 'God's honour by thinking that His Essence is found in lowly and dishonourable physicality and even in despicable things, God forbid.' 5 Note that the problem isn't simply Kundera's problem with excrement. The problem is God's coexistence with anything as coarse as physical matter. But note also that this problem reaches something like its pinnacle in Kundera's problem, since it's one thing to conceive of God coexisting with 'dishonourable physicality' and another thing to think of him coexisting even with 'despicable things', such as excrement. The doctrine of God's contraction solves the problem of God's coexistence with physicality, and so too, with filth.

Later, Rabbi Ricchi writes that 'the lack of honour ascribed to the King when saying that He oversees filth from His window is not comparable to [and thus nowhere near as bad as] the lack of honour, God forbid, when saying that the King Himself is within [the filth] itself'. ${ }^{6}$ Yes, God can create filth, but he can't be present in it. It exists in a godless space for which his contraction made room. 
Other Lurianic Kabalists are concerned that we cannot take the doctrine of tzimtzum - Divine contraction - literally. God cannot rein Himself in, because God - essentially - fills all of Being. That's part of what it means to be God. ${ }^{7}$ To navigate round this difficulty, God must create an illusion of there being a space beyond Him; an illusion of a withdrawal. Our entire creation exists within the space that that withdrawal creates. And yes, there's a sense in which our entire creation is, like the space in which it exists, nothing more than an illusion. This is the doctrine of non-literal Tzimtzum.

Yes, there's a sense in which the creation isn't real. But what matters to us, and what should matter to us, is what is real within the illusion; not what's real beyond it. God's glory, in actual fact, is everywhere. But, from our perspective, it is concealed. And that concealment is what makes room for our very existence. Moreover, it is this concealment which, according to Rabbi Chaim of Volozhin (1749-1821), in his masterpiece, Nefesh HaChayim (3:5), makes room for 'different types of places: places which are holy and pure, and their opposite, which are impure and filthy'. ${ }^{8}$ And indeed, it is the existence of impure and filthy places within the illusion, or dream, or story that we call this world, that provides the 'framework of obligation that we have been commanded from God's mouth as an immutable decree' ${ }^{9}$ - such as the command to bury our faeces and not to think about the Torah while we're on the toilet.

From God's perspective our world isn't real. All that's real is Him in his holiness. But we exist in something like a story. In the story, it's true that God isn't everywhere. Some places, in this world, are filthy.

In this way, whether it's taken literally as Rabbi Ricchi takes it, or metaphorically as Rabbi Chayim takes it, the doctrine of Tzimtzum makes room for the existence (according to Rabbi Ricchi) or relative existence (according to Rabbi Chayim) of filth.

There are religions that revel in every aspect of nature. They claim that everything natural is holy because everything natural was created by God. In the Rabbinic imagination, the religion that most lived up to this ideal was the religion of the false god, Baal Pe'or. When a woman asked the priests of Baal Pe'or how to worship their god, they told her (tractate Sanhedrin 64a): 'One eats spinach, [which causes diarrhoea,] and drinks beer, [which also causes diarrhoea,] and defecates before it.' ${ }^{\prime 0}$ A Jewish man went into their temple to demonstrate his disgust at their idolatry (ibid.):

He entered and defecated before [the idol,] and wiped [himself] with its nostril. But [he found that he was unsuccessful in his attempt to demean their god, since] the priests [of Pe'or] were praising him and saying: No person has ever worshipped it [before] with this [excellent form of worship]! ${ }^{11}$

Judaism, on this view, would define itself against the cult of Baal Pe'or. We do not think that a thing is holy just because it's natural. ${ }^{12}$ On the contrary, the creation itself is only made possible by God's act of self-contraction or concealment. This act 
made room for the existence of the unholy and the filthy. Our job, as servants of God, even if it's only within the story of this world, is to cling to the holy, and to avoid the filthy. Our task - the way in which we accrue merit - is to elevate the godly within us, and to leave behind the animalistic as far as is possible. We are in the image of God, but it's only a pale reflection. Indeed, if only we were more holy, we wouldn't have bodies at all, and we certainly wouldn't defecate.

To back this up, one could cite the following discussion in the Talmud (tractate Yoma, 75b). The Rabbis were debating the manna that fed the Israelites in the wilderness. According to Rabbi Nachman bar Yitzchak, and Rabbi Yishamel, it seems that one of the defining features of manna was that it would be totally digested, leaving no need for defecation. But then the Talmud asks: how can we make sense of the biblical injunction to bury our excrement? The obvious answer would be that this injunction only became relevant once the Jews had entered the holy land and ceased to be fed by the heavens. But instead, the Talmud suggests that the Jews did poo in the wilderness, but only because their diet wasn't exclusively based upon manna. They supplemented their menus with other things; they bought food from travelling merchants. At this point, Rabbi Elazar ben Perata raises an objection:

Rabbi Elazar ben Perata [disagrees and] says: The manna even caused items that the gentile merchants sold them to be [completely] digested, [so that even the other food that they ate produced no waste. $]^{13}$

The manna was so miraculous that, even if it were eaten in combination with other foodstuffs, a human being would not need to excrete. But this just raises the question again: why the commandment to bury the faeces (if there was no faeces)? Rabbi Elazar answers:

After [the Israelites] sinned, [the manna was not as effective.] The Holy One, Blessed be He, said: I [initially] said [that] they would be like ministering angels [who do not produce waste]; now I will trouble them to walk three parasangs [to leave the camp in order to relieve themselves]. ${ }^{14}$

The very fact that we defecate is a sign of our lacking holiness. It is a sign of our sinfulness. We are created in the image of God, but we are still a pale reflection of divinity. We don't embrace Kundera's categorical agreement with being (or, at least, not without qualification), and we recognize filth for what it is. Rather, our job is to cling to the holy, and that's why Judaism ritualizes what might be called the poo-taboo.

\section{Response 2: God's creation cannot contain filth}

Rabbi Chaim of Volozhin accepted that there's a certain perspective - so to speak, a God's eye perspective, from which the world is just an illusion, and everything is God. Nevertheless, Rabbi Chaim was acutely aware that this doctrine was 
liable to be misunderstood (Nefesh HaChaim 3:3). Indeed, we can see how it could lead people to the extravagant vulgarities of Baal Pe'or. Instead, we have to live our lives from the perspective of the creation; not from the perspective of the creator. And from our perspective, there are holy places and unholy places; clean places and filthy places. We must respect those distinctions.

Rabbi Chaim's philosophy was a reaction to Hassidism. In particular, the great systematizer of Hassidic thought was Rabbi Shneur Zalman of Liadi (1745-1813) the first Grand Master of the Lubbavitch sect of Hassidism. Rabbi Shneur Zalman wrote (in Part I, Chapter 33, of the Tanya) that 'the true joy of the soul' is only attained when a person is able to live, so to speak, on two levels simultaneously to function in the world of creation, but to be constantly aware that the only true reality, from the point of view of the Creator, is God.

When one will deeply contemplate this, his heart will be gladdened and his soul will rejoice even with joy and singing, with all heart and soul and might, in [the intensity of] this faith which is tremendous, since this is the [experience of the] very proximity of G-d, and it is the whole [purpose] of man and the goal of his creation, as well as of the creation of all the worlds, both upper and lower, that He may have an abode here below...

Behold, how great is the joy of a common and lowly man when he is brought near to a king of flesh and blood, who accepts his hospitality and lodges under his roof? How infinitely more so is the [joy in the] abiding nearness of the Supreme King of kings, the Holy One, blessed be He. ${ }^{15}$

There is no joy for the soul greater than the realization that God 'permeates all worlds, both upper and lower, and even the fullness of this earth is His blessed glory; and how everything is of no reality whatever in His presence; and He is One Alone in the upper and lower realms' ${ }^{16}$ For Rabbi Chaim of Volozhin, this was a truth to be hidden; reserved only for an elite and ignored by all in our day-to-day reality. Even if we're akin to characters in a story, it is for us to ignore that fact and live within the story. For Rabbi Ricchi, the notion that God permeates all worlds was a disgrace to be denied, for it relegated God from looking at the filth, from the window, to standing in its midst. For Rabbi Shneur Zalman, by contrast, this was a truth, and it was something that the common and lowly man should rejoice in, recognize, and internalize. God is everywhere. God is in everything. Everything is holy. Everything is illuminated.

This view embraces the categorical agreement with being, without any qualification. Moreover, if everything is a projection of God, then every facet of His creation reflects back upon Him. We cannot say that we are in His image except for when we're defecating. We are, limb for limb, in the image of God. This doesn't mean, of course, that God has a body, but it also doesn't mean that our bodies are irrelevant to the sense in which we're in God's image.

Franz Rosenzweig suggests that when the Bible talks of God having a hand, we needn't think that it's a metaphor. God really has hands, even if they're not physical. Our hands, by contrast, they are just metaphors. They are metaphors for God's hands. They reflect some divine ability or attribute of God. Every part of the human 
creation is somehow or other in the image of God, and so too is every element of the creation beyond the human. ${ }^{17}$

But two questions haunt this more Hassidic approach to God's creation. First of all, if we're supposed to live with the realization that God is everywhere, and that nothing is filthy, then how are we to make sense of the Jewish laws that enshrine the poo-taboo? ${ }^{18}$ Second, and much more worryingly, we seem forced to ask a rather sacrilegious question: if we're to embrace the categorical agreement with being, and to see the godliness even in faeces, and if we're to embrace an associated understanding of what it means to be in the image of God, are we to say that God Himself defecates; that our excrement is, somehow, in the image of God? I address these questions one by one.

\section{Question 1: how to make sense of the poo-taboo?}

Henry Thoreau, much like the Hassidic masters, believed that the human spirit can 'transmute what in form is the grossest sensuality into purity and devotion'. One way to elevate even the ugliest phenomena is to embed them into a language of ritual. He writes in tones of praise about Hindu law, which places every bodily function within its regulatory purview: 'Nothing was too trivial for the Hindoo lawgiver, however offensive it may be to modern taste. He teaches how to eat, drink, cohabit, void excrement and urine, and the like, elevating what is mean, and does not falsely excuse himself by calling these things trifles.' ${ }^{19}$ Wendell O'Brien presumes that the Hindu lawgiver in question was Manu, or someone similar. This just leaves O'Brien confused. Most of Manu's excrement regulations are just good sense, from a hygiene point of view. They don't seem particularly enlightened, from a spiritual point of view.

\footnotetext{
Don't urinate into the wind, nor in an inhabited cave, nor while walking. Don't defecate in public. Don't put excrement in the drinking water. Never eat the feces of crows, pigs, camels, and monkeys, if you can help it. Don't intentionally step in any sort of excrement, whether animal or human. Dispose of your own excrement far away from your dwelling place. When you've finished your business, clean your organs thoroughly, taking care to remove any stray fecal matter from your body, clothes, and things. If (in an emergency) you have to defecate on the royal highway, get somebody to clean it up before you move on.

With all due respect to Thoreau, I must say that I can't see how any of this elevates excretion and turns it into purity and holiness. Manu's injunctions all seem to me to presuppose that it is a nasty business whose products are revolting. Feces and urine - I don't know what happened to gas - make his list of the 'twelve bodily defilements,' which also includes nice things like snot and earwax. You shouldn't even look at such things, he says, and defecation is such a defilement that you must not even think of reciting the Veda on the potty. ${ }^{20}$
}

But I think that O'Brien entirely misses Thoreau's point. Even if the rules of excrement, like those of Jewish law, and like those of Manu, create a taboo around poo, they also elevate it. To forbid holy thoughts, as a matter of religious law, while on the toilet - which clearly isn't for hygiene purposes, is actually to enfold one's 
sitting on the toilet into the woof and warp of one's religious life. To recognize the ugliness of faeces, and its risk to public hygiene, but to translate that recognition into the language of ritual is precisely to elevate it. It is to refuse to believe that anything is beyond the purview of religion, and sanctification. Even if we feel filthy when our bodies contain excrement, we elevate that entire experience by promoting the common-sense pre-prayer voiding of the bowels into a Torah requirement.

The Bible says that uncovered faeces is unseemly. But perhaps what's unseemly isn't the faeces, but our failure to cover it. Not because it's irredeemably disgusting, in any objective sense, but because our failure to cover it is a failure to redeem the disgusting; it's a failure first of all to register our disgust, and then second to elevate it, and to give it significance in the language of ritual. Admittedly, this approach will find it hard to relate to Rabbi Elazar ben Perata's opinion that our defecation is a consequence of our sinfulness. But his opinion was one of many in the Talmud, and could simply be discarded in favour of the views of his interlocutors.

Rabbi Ricchi can make sense of the poo-taboo by insisting that excrement is filthy and devoid of godliness. Rabbi Chaim can make sense of the poo-taboo by insisting that even though God permeates everything, poo is still filthy from our perspective. In other words, and in order to uphold the infrastructure of Jewish law, we must pretend - so to speak - that holiness cannot be found in the bathroom. We must pretend that we reject the categorial agreement with being. The Hassid, by contrast, can make sense of the poo-taboo without relinquishing the joy of recognizing that God is everywhere, and in all places. We recognize this all-pervasive Godliness by enfolding every experience, even the ones which appear to us to be devoid of holiness, into the language of Jewish ritual. The followers of Ba'al Pe'or would encourage us to relish the disgusting; to deny or overcome the visceral human response that we have to it. The Hassidic way, by contrast, is to recognize our disgust, and to place it into the context of a ritual.

Let us not forget to mention: after the spiritual silence of the toilet, upon which holy thoughts cannot be thought, there is a benediction to be said upon leaving the toilet; a benediction which praises God for the design and function of the human digestive system. From beginning to end, the toilet experience is embraced, and elevated, by Jewish law. Thoreau would have been proud.

Now, you might well ask: 'isn't unredeemed filth also godly, if everything is godly? What added value stems from our acts of redeeming the ungodly?' This question raises, in turn, a deeper question about how to square Hassidic metaphysics with the need for any religious activity. If everything is perfect as it is, then why bother to act? Indeed, doesn't Hassidic metaphysics lead inexorably to quietism? Although this larger question goes beyond the scope of this article, I think we can begin to sketch an answer. Yes, everything is godly, with or without our acts of redemption. But part of how we serve God is to redeem in our minds what, to $u s$, seems - at first - ungodly. The real work here is psychological rather than metaphysical. 


\section{Question 2: does God poo too?}

The question is almost too absurd to attempt to answer. But Kundera's dilemma forces it upon us. If we're to embrace the categorical agreement with being, then we're almost bound to say that our being in the image of God extends to every feature of our design. Again: this isn't to say that God has a body, but it does entail that every part of our body is somehow a reflection of the Divine. But if that's what we're led to say, then, in what sense is our excrement, and our need to defecate, a reflection of divinity?

Michael Wyschogrod comes close to raising the question. He discusses, and rejects, the Neo-Platonic theology of emanation. According to that theory, God is Absolute perfection. This Absolute is unchanging. No activity can be ascribed to it, because it has no need, and no unspent potential to actualize. It has every perfection already. To explain the creation of our world, the Neo-Platonist has to appeal to the notion of emanation. Wyschogrod explains:

Emanation is to be understood as an overflow. The fullness of the Absolute is so great that it overflows, and the trickling down of this overflow is the creation of the world. Two aspects of the concept of overflow or emanation must be understood if the proposed solution is to be grasped. An overflow is not an action. It is not a goal-directed undertaking, as creation is. God as creator must have had a purpose and if he had a purpose he was incomplete and therefore not perfect. But an overflow as a spontaneous discarding of unneeded excess does not constitute purposive action and therefore is compatible with a notion of the Absolute. But what is even more important is that such a discarding of excess does not diminish the Absolute... The world exists only from its point of view but is nonexistence from the point of view of the Absolute. The world is refuse of the Absolute. It is as if a wealthy man discarded something that had no value to him but that constituted a treasure for the pauper who found it . . ${ }^{21}$

Wyschogrod rejects this entire model as incompatible with Jewish theology. Even those Jewish mystics who sought to adopt a Neo-Platonic theology felt compelled to amend it. Even at the expense of its coherence, they had to imagine some moment in which the Absolute made a choice; a choice to begin its emanations. Without this choice, the world is nothing but God's discarded excess; his refuse; his excrement. Wyschogrod's rejection of Neo-Platonic emanation could be summed up in the following slogan: God does not defecate; He creates.

A much earlier source raises the same possibility and comes to the same conclusion. The Talmud (tractate Avodah Zarah 17a) tells a story of a man called Elazar ben Dordayya. He was very promiscuous. He made a point of visiting every prostitute that he heard of. He would travel the world in pursuit of this policy. Once, he travelled a particularly long way to visit a prostitute who charged an exorbitant fee. In the midst of their meeting, however, the prostitute in question 'blew wind' ('הפיחה') - a euphemism for breaking wind. She was, perhaps, embarrassed. And, perhaps in order to shield her embarrassment, she lashed out and said: 'Just as this wind [that I passed, will] not return to its place, so too Elazar ben Dordayya will not be accepted in repentance.'22 
We should remember that God blew the breath of life into Adam. This initial kiss of life, so to speak, came from God's mouth into Adam's nostril. To understand the full significance of the prostitute's insult, we have to compare Adam and Elazar. God's mouth can exhale and inhale. Just as he breathes life into our nostrils, he will - at the end of our lives - breathe us back in. Our destiny is to return to God. But Elazar cannot return. Elazar's breath of life didn't come from God's mouth. Elazar's life came from God breaking wind. Such a life will never return to its maker. Elazar is God's refuse.

No wonder that Elazar was shocked. So shocked was he that he resolved to mend his ways and repent. His degradation was so entrenched that repentance was no easy task. Indeed, the sheer emotional and psychological effort to repent was enough to kill him. But, the Talmud makes it clear that when he died, because of his great remorse and his efforts to repent, he was accepted into heaven. The prostitute's insult was insightful insofar as it was exactly what Elazar needed to hear, in order to repent. But her insult wasn't true. God breathes life into us, but God doesn't break wind.

And so, we're struggling now to make sense of the notion that human defecation could in any way be a reflection of the Divine. Jewish tradition seems to teach us, in no uncertain terms, that there's nothing divine about defecation.

But I would like to make a suggestion. Together with Tyron Goldschmidt (Lebens \& Goldschmidt, 2017), I have argued that God will one day return to history, in order to edit it. There are a number of Jewish sources that seem to point in this direction. Indeed, God promises: 'I, even I, am He that erases your transgressions for my own sake; and your sins I will not remember' (Isaiah 43:25). ${ }^{23}$ This could be read as a promise that, in the end of days, God won't remember our sins - not because he'll rein in his omniscience and, per impossibile, forget them, but because he will change history; he will make it such that we didn't sin; he will erase our transgression; and since our sins won't be there, God will not remember them.

Tyron Goldschmidt and I traced a number of Hassidic and other sources that describe God's power and promise to change the past. Moreover, we sought to explain why God might want to wait, until the end of time, before deciding to edit certain blemishes. I quickly reconstruct our argument.

Imagine that God gives us free will and then, so to speak, he says, 'Take 1'. Then we live our lives. We do some good and we do some bad. All of it is of our own creation. At the end of time, God can say, 'Cut'. Imagine that scenes 1 and 3 are fantastic, but that scene 2 is horrific. God can could then say, 'Scene 2, take 2'. We'd then get another shot at linking scenes 1 and 3 together.

Take 2 of scene 2 would, once again, be of our own authorship. God is a patient director. He can commission a take 3, or 4, or however many more takes are required. Every evil that now exists will one day never have existed. ${ }^{24}$ The evil things that people do in early takes aren't just temporary, they are what philosophers might call hyper-temporary. A temporary evil is one that doesn't last 
forever. A hyper-temporary evil, by contrast, is one that will one day never have existed at all - once the past has been edited. ${ }^{25}$

By allowing evils to exist hyper-temporarily, God can have the best results of free will - all goods will be of our own creation, and all rewards will have been justly rewarded - but eventually, it will be the case that nobody will have done any bad; nobody will have suffered. On this view: God can have his cake and eat it too.

On this theory: God is like a proofreader who allows us to write our own biographies, since he values our freedom, and he wants us to earn our own rewards, but once we're finished, he asks us to rewrite the passages that need editing. Free will might not be a worthy price to pay for evils that are always going to exist (as many philosophers - atheist and theist alike - have insisted). However, free will might be worth the price of hyper-temporary evils that will one day never have existed. Thus, God is able to give us all free will and ultimately to ensure that we will never have abused it. We called this the Divine Proofreader Theory.

Of course, there are lots of objections to answer, and wrinkles to iron out. But imagine that it's true. On this assumption, it turns out that God's creative activity involves a process of editing, redrafting, and reshaping. This process is echoed in human creativity.

When we create something, we often start out by saying more than we want to say, laying out lots of ideas, as they rise to our consciousness, and then, at a later stage, we have to be judicious. Part of creating is deciding what we're happy with, and what we want to change, and to perfect. Our bodies embody this insight. To create a human child, the father ejaculates millions of sperm cells; the egg of the mother accepts just one. All of the other cells are spent possibilities, they are refuse. The human body consumes food. It absorbs what it wants to take from the food, and it excretes the rest. In this way, even our excrement is a reflection of something divine. Namely: the process of creation which starts with more and ends with less. ${ }^{26}$ One needn't go so far as the somewhat idiosyncratic Divine Proofreader Theory. The Midrash talks of God creating and destroying worlds before creating this one (Bereshit Rabba 3:7). Another Midrash describes demons as something like cast-offs of God's creation process (Tanchuma, Bereshit 17). ${ }^{27}$ Again: the process of creation starts with more and ends with less.

We asked the question: can God's creation contain filth? We saw two answers. Rabbis Ricchi and Chaim would insist that - if only from a certain perspective it can. Our task is to transcend nature, and its filth. The Hassidic answer, by contrast, is that God's creation cannot truly contain filth, and that the holiest and most joyful existence comes to those who are able to see Godliness in everything.

We then saw that two questions arise for the Hassidic approach. Can it make sense of the Jewish laws that enshrine the poo-taboo? And we found that it could. These laws serve as a vehicle for redeeming what appears to us to be disgusting and enfolding it within the language of religious ritual. The taboo itself is what psychologically elevates the seemingly filthy, and redeems its holiness 
from within it. The second question was this: can we truly relate to human excrement as somehow a reflection of something divine? And we found that we can. The biology of defecation can be thought to express a fact about divine creativity. ${ }^{28}$

\section{References}

CurTis, V. A. (2007) 'Dirt, disgust, and disease: a natural history of hygiene', Journal of Epidemiology and Community Health, 61, 660-664.

Curtis, Valerie \& Biran, Adam (2001) 'Dirt, disgust, and disease: is hygiene in our genes?', Perspectives in Biology and Medicine, 44, 17-31.

Goldschmidt, Tyron \& Lebens, Samuel (2019) 'Divine contractions: theism gives birth to idealism', Religious Studies.

Horwitz, RivKa (1969) 'Franz Rosenzweig's unpublished writings', Journal of Jewish Studies, 20, 57-80.

Kelly, Daniel (2011) Yuck! The Nature and Moral Significance of Disgust (Cambridge MA: MIT Press).

Kundera, Milan (1995) The Unbearable Lightness of Being (London: Faber \& Faber).

LeBens, SAmuel (2017) 'The life of faith as a work of art: a rabbinic theology', International Journal for Philosophy of Religion, 81, 61-81.

Lebens, Samuel \& Goldschmidt, Tyron (2017) 'The promise of a new past', Philosophers' Imprint, 17, 1-25.

O'Brien, Wendell (MS) 'Philosophical reflections on excretion'.

Rozin, Paul, Haidt, John \& McCauley, Clark (2008) 'Disgust', in Lisa Felman Barret, Michael Lewis, \& Jeannette M. Havilan-Jones (eds) Handbook of Emotions, 3rd edn (New York: Guilford Press), 757-776.

Thoreau, Henry (1995) Walden: An Annotated Edition (Boston: Houghton Mifflin).

Wyschogrod, Michael (1996) The Body of Faith: God in the People Israel, 2nd edn (Lanham MD: Rowman \& Littlefield).

\section{Notes}

1. See, for instance, the comment of Rabbi Meir HaKohen (Hagahot Maimuniot), in his comments on Mishne Torah, Prayer and Priestly Blessing, 4:10, as cited by Rabbi Moshe Isserlis in his gloss on the Shulchan Aruch, Orach Hayyim, 92:1.

2. Curtis \& Biran (2001); Curtis (2007). Daniel Kelly $(2011,28)$ points out that our sense of disgust enforces a "no re-entry" policy for bodily fluids and excreta. This policy will play a beneficial role in human hygiene.

3. I take responsibility for translations in this article, although I did consult a number of older translations. To avoid any doubt, I will provide the original language in these notes. This verse, in the original Hebrew, reads: כי ה' אלקיך מתהלך בקרב מחנך להצילך ולתת איביך לפניך והיה מחניך קדוש ולא יראה בך ערות דבר ושב מאחריך :

4. Readers interested in unpacking these metaphors into a more rigorous philosophical argument should see Goldschmidt \& Lebens (2019).

5. Yosher Levav, Batei HaLev, Bayit 1, Cheder 1, chapter 12. In its original Hebrew, reads: יפגום בכבודו בחשבו שעצמותו נמצא גם בגשמיים השפלים הבלתי נכבדים ואף בנבזים חס ושלום

6. Ibid., ch. 13, in the original Hebrew: שאינו העדר כבוד שנאמר שהמלך משגיח מחלונו דבר לכלוך כמו שהוא העדר כבוד שנאמר חס ושלום שהמלך עצמו בתוכו

7. Again, for a more rigorous unpacking of these metaphors, see Goldschmidt \& Lebens (2019).

8. In the original Hebrew: מקומות שונים מקומות קדושים וטהורים ולהיפך טמאים ומטונפים

9. In the original Hebrew: שעפ"י זאת הבחי' נבנו כל סדרי חיוב הנהגתינו שנצטווינו מפיו ית' חק ולא יעבור

10. In the original Aramaic: אוכלין תרדין ושותין שכר ומתריזין בפניה

11. In the original Aramaic: נכנס פער בפניו וקינח בחוטמו והיו משרתי ע"ז מקלסין לו ואומרים מעולם לא היה אדם שעבדו לזו בכך

12. See: https://www.etzion.org.il/en/our-eternal-battle-ideology-peor 
13. In the original Aramaic: ר"א בן פרטא אומר אף דברים שתגרי אומות העולם מוכרין להן מן מפיגן

14. In the original Aramaic: לאחר שסרחו אמר הקב"ה אני אמרתי יהיו כמלאכי השרת עכשיו אני מטריח אותם שלש פרסאות

15. In the original Hebrew:

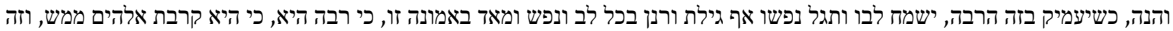

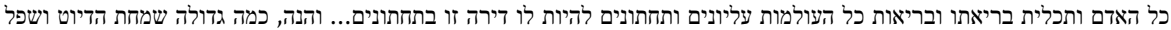

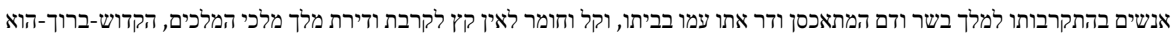

16. In the original Hebrew:

הוא ממלא כל עלמין, עליונים ותחתונים, ואפילו מלא כל הארץ הלזו הוא כבודו יתברך, וכולא קמיה כלא חשיב ממש, והוא לבדו הוא

בעליונים ותחתונים ממש כליו, עליונ

17. Horwitz (1969), 74.

18. Of course, one way to avoid this question is to deny that Jewish law really does endorse a poo-taboo. It is possible to reinterpret all of the laws that seem to register a recognition of the objective filthiness of faeces, and other seemingly filthy objects. Perhaps these laws are motivated only by considerations of hygiene, rather than disgust. Perhaps Jewish law can be thought to be in conversation with human culture such that if we subjectively find an object disgusting, the law will take that fact into account without necessarily endorsing that the objects are, in any objective sense, disgusting. Perhaps, in line with what Maimonides argues in Part 3, chapter 8, of the Guide to the Perplexed, these laws are designed to inculcate a sense of shame towards our own materiality, in order to help us perfect our intellect. This last, Maimonidean suggestion doesn't necessarily entail that our materiality is, in any significant sense, objectively filthy. This footnote is owed to an anonymous reviewer.

19. Thoreau (1995), 215-216.

20. O'Brien (MS).

21. Wyschogrod (1996), 94.

22. In the original Hebrew:

כשם שהפיחה זו אינה חוזרת למקומה כך אלעזר בן דורדיא אין מקבלין אותו בתשובה

23. In the original Hebrew:

אנכי אנכי הוא מחה פשעיך למעני וחטאתיך לא אזכר

24. This thought cannot be easily expressed in English because English doesn't have the right sort of tenses to describe revisions of the past. You actually need hyper-tenses. The real claim is this: it hyper-will be the case that no evil ever happened. But hyper-tenses need to be explained at length. I refer interested readers to Lebens \& Goldschmidt (2017).

25. Again: for more on the meaning of hyper-tenses, see Lebens \& Goldschmidt (2017).

26. A reviewer notes that the analogy would be tighter if God didn't edit the bad bits out of existence altogether. As they put the question: "If we take the analogy between defecation and discarding-in-thecourse-of-creation seriously, then since the feces are real and present when all is said and done, wouldn't the analogy be tighter if God didn't edit the unwanted takes out of existence?" I would respond as follows: on the Divine Proofreader Theory, the unwanted takes do actually leave something like an ontological shadow. So, something is left to correspond, in this analogy, to faeces. These ontological shadows are called hyper-backward-looking properties. For more details, see Goldschmidt \& Lebens (2019).

27. For more on this reading of this Midrash, see Lebens (2017), 65-66.

28. My thanks to Yujin Nagasawa for his patience, grace, and judiciousness, and Tyron Goldschmidt for his comments and suggestions. Thanks also to the anonymous reviewers who provided me with useful comments. If anybody is offended by the subject matter of this article, please address your complaints to the incorrigible Professor Scott Davison. 